\title{
The power of the Blessed Sacrament: the iconography of the hosts in the 15th and 16th centuries
}

\author{
El poder del Santísimo Sacramento: la iconografía de la \\ sagrada forma en los siglos XV y XVI
}

\author{
Ana Cristina SOUSA \\ Universidade do Porto
}

Recibido: 14-III-2016

Aceptado: 27-IV-2016

Aвstract: The Synodal legislation, the Visitation Books and the Inventories of diocesan and parish church treasures from the mid $15^{\text {th }}$ to mid $16^{\text {th }}$ century frequently refer to the existence of "tools for making hosts" and their state of conservation, stating that they should be replaced when inadequate and acquired when absent. The hosts were made on site, normally in the sacristies, and carefully prepared in accordance with a choicely conducted ritual, taking care with the origin and quality of the materials and utensils used as well as the conditions of those responsible for the preparation of the oblate. Based on a comparison of the aforementioned literature with the "host moulds" that have survived to the modern day and contemporary paintings, the iconography used on the Hosts will be analysed and their liturgical and symbolic meanings reflected upon*.

Keywords: Eucharist, Elevation, Transubstantiation, Consecrated Species, Hosts Moulds, Hosts, Iconography.

Resumen: La legislación sinodal, los Libros de Visitas y los Inventarios de los tesoros de las Iglesias diocesanas y parroquiales desde mediados del siglo XV hasta mediados del XVI recogen frecuentemente la existencia de "moldes para hacer hostias" y su estado de conservación, estableciendo que debían ser reemplazados cuando eran inadecuados o adquiridos cuando no existían. Las formas se fabricaban in situ, normalmente en las sacristías, y se preparaban con cuidado, de acuerdo con un ritual cuidadosamente realizado, con especial preocupación por el origen y calidad de los materiales y herramientas utilizados, así como por las condiciones de los responsables de la preparación de las mismas. Basándose en la comparación de la literatura mencionada anteriormente con los "moldes de hostias" que se han conservado hasta la actualidad y con pinturas coetáneas, se analizará la iconografía utilizada en las formas y su significado litúrgico y simbólico.

Palabras clave: Eucaristía, Elevación, Transubstanciación, Formas consagradas, Moldes para hostias, Hostias, Iconografía.

\footnotetext{
* Translation of the original text: Mark Poole
} 


\section{TRUE BODY, TRUE BLOOD}

"Ho Santíssimo Sacramento da Eucharistia foy instituydo por nosso Redemptor na sua despedida e ultima cea que com seus discípulos fez, com summa charidade e imenso amor" ${ }^{2}$. This text, included in the Synodal Constitution of Angra do Heroismo in 1560, records Christ's initiation of the Eucharist at the Last Supper and explains the superiority of this Sacrament demonstrates "in itself the divinity of our Redeemer and his sacred soul and true body" ${ }^{\prime \prime}$. The same idea can be seen in the Braga Synod of 1477, which demands devotion, solemnity and composure from the clerics during Mass, "porque antre todollos oficios divinos a missa tem maior excelencia, sanctidade e perrogativa por honrra e reverença do sanctissimo e preciosissimo Corpo e Sangue de nosso Senhor Jhesu Christo que em ella hé consagrado e adorado(... $)^{\prime \prime 4}$. The theory presented in Portuguese legislation reflects a long period of discussion and reflection on the question of consecrated species during the Middle Ages. The Eucharist is very early on understood as being a very special Sacrament, the most sacred of the Church, but the problem of the Transmutation of Species is one theologians debated in depth throughout the $12^{\text {th }}$ and $13^{\text {th }}$ centuries. During this period the term transubstantiatio is used for the first time to explain the substitution of bread and wine for the body

\footnotetext{
${ }^{1}$ Translator's note: Parts of the article are quoted from 15th and 16th century documents. These are left in the original Portuguese or Spanish and translated as footnotes.
}

2 "The Blessed Sacrament of the Eucharist was instituted by our Redeemer upon His farewell at the Last Supper with His disciples, with immense charity and love."

${ }^{3}$ A. J. da COSTA, "A Santíssima Eucaristia nas Constituições Diocesanas Portuguesas desde 1240 a 1954", Lusitania Sacra, 2ª série, t. I, 1970, p. 207.

4 "Among all divine offices the mass has the largest excellence, sanctity and prerogative for the honour and reverence of the sanctity and preciousness of the Body and Blood of our Lord Jesus Christ which in it is consecrated and adored." F. CANTELAR RODRÍGUEZ, Synodicon Hispanum. Portugal, Madrid, 1982, vol. II, p. 84. and blood of Christ ${ }^{5}$ because in fact, as Miri Rubin mentions, "now bread, now God, the host showed little change" ${ }^{\prime \prime}$. The concept was approved at the Fourth Lateran Council in 1215, when the dogma of Transubstantiation was promulgated. It demanded love, devotion and purity of soul among the clerics who celebrated the Holy Eucharist and a full awareness that this moment was testament to the full sacrifice of the Redeemer. Known as "particle", has received the name of hostia, Latin word that means "victim", an allusion for Christ, the Agnus that offers Himself to God for the Salvation of Humanity ${ }^{7}$.

The ritual of Mass and the cult of the Holy Sacrament are, in this context, heavily promoted by the Church, extolling, in particular, the moment of consecration, with it being enriched by a number of complex gestures, colours and sounds which converted it into a carefully thought out ceremony directly aimed at the feelings of the faithful. The miracle of Transubstantiation occurs with the words offered by Christ at the Last Supper, the same as those pronounced by the priest: hoc est corpus meum ${ }^{8}$. Thus, the ritual of the Elevation of the Host was created. It was done so to highlight the moment of consecration, which guarantees the faithful an opportunity to "see God" and offers a "spiritual union with Christ" since contemplation is enough for there to be a symbolic and "spiritual communion" ${ }^{\prime \prime}$. This liturgical gesture accen-

${ }^{5}$ F. TIXIER, La Monstrance Eucharistique. XIII-XVI siècle, Rennes, 2014, p. 31.

${ }^{6}$ M. RUBIN, Corpus Christi. The Eucharist in Late Medieval Culture, Cambridge, 2004, p. 53.

${ }^{7}$ M. E. SÁNCHEZ SANZ, "La elaboración del pan eucarístico en el convento del Santo Sepulcro de Zaragoza, hoy Monasterio de la Resurrección", Temas de Antropologia, $\mathrm{n}^{\mathrm{o}} 21,2015$, p. 9 .

${ }^{8}$ Gesture and ritual defined, for the first time, in the Synodal decree of Eudes de Sully, bishop of Paris between 1196 and 1208. M. RUBIN, Op. cit., p. 55.

${ }^{9}$ The Council of Lateran reduced the communion of the faithful to Easter Sunday, a measure aimed at reducing abuses and superstitious beliefs. P. S. DEL POZO COLL, "La devoción a la hostia consagrada en la Baja Edad Media castellana; fuentes textuales, materiales 
tuates the sacredness of the mystery of the Eucharist and responds to the need of the faithful to contemplate and adore the Corpus Christi during the Mass. Furthermore, it adds to the belief in the apotropaic action of the consecrated bread, which protects against disease, death and loss of eyesight. The elevation of the species thus became a great motivation for Catholics to attend mass. The visitors admonished the faithful that on Sundays and feast days, muttering and mumbling would remain outside the building, with only those entering the church "when they were raised to God". This constitutes an indirect example of the devotion to the Consecrated Species and to the privileging of the ritual of the Elevation revealed by the faithful in Portuguese parishes at the beginning of the sixteen hundreds ${ }^{10}$. This situation is also referred to in other European countries. Attentive to the constant warnings in the documentation, Torres Jiménez considers that the custom of many faithful of remaining outside of churches on Sundays and feast days, waiting in the streets, squares and surroundings for "the sound of the bell at the moment the Host was raised" must have been widespread and constitutes the biggest proof of the population's devotion to the Eucharist. The Eucharistic ritual was equally fundamental for the priests and many of these determinations allowed them to judge the importance the Church gave to this special moment ${ }^{11}$.

e iconográficas para su estudio", Anales de Historia del Arte, no 16, 2006, p. 28.

${ }^{10}$ These admonishments are frequent in the Visitations of the parish churches of the Military Orders of Avis and Santiago, in Portugal, carried out throughout the first half of the 16th century. Given as examples are the Visitations to the churches of Palmela (1510), Cano (1519) e Seda (1539). M. R. S. B. RAMOS, As igrejas de Palmela nas Visitações do século XVI. Rituais e manifestações de culto, Palmela, 2011, p. 139 and J. M. M. L. S. MENDONÇA, A Ordem de Avis revisitada (1515-1538). Um entardecer alheado, Doctoral Thesis defended at the University Lusíada of Lisbon, 2007, vol. II, pp. 241 and 472.

${ }^{11}$ M. R. TORRES JIMÉNEZ, Formas de organización y práctica religiosa en Castilla La Nueva. Siglos XIII-XVI, Doctoral Thesis defended at the Universidad Complutense de Madrid, 2002, pp. 1816 and 1233.
The devotion to the Holy Sacrament led to the need for It to be held back with the aim of allowing communion for the infirm. This led to great care being taken and resulted in the appearance of new objects aimed at conserving It. The cult of the Blessed Sacrament was strongly encouraged by the Church. The belief in the real presence of Christ in the consecrated species and the respect they were given, the adoration of the Blessed Sacrament and the wish on the part of the faithful to contemplate the Body of the Lord, also explain the appearance of new iconographic programmes, new devotional practices and new festivities. These led to an increase in reports of Eucharistic miracles recognised in Western Christianity from 1200 onwards, as well as the appearance of iconographic themes which accentuated Christ's humanity, the practice of Imitatio Christi, particularly among the Flagellant Brotherhoods, and the beginning of the Corpus Christi procession in 1264, authorised by Urban IV's papal bull: Transiturus de hoc mundo. The faithful needed to "feel" the Divinity and to become closer to Him, reaching God through the son, the Good Jesus, the Suffering Jesus, the Holy Body, the target of the greatest devotion $^{12}$. The image of Jesus is humanised, and His suffering, the moments of Passion and participating in the redemptive Death are relived. It is in this context that "true body" of Christ present in the consecrated Host demanded very particular cares and attentions.

\section{MAKING THE HOSTS}

The making of the Eucharistic bread was understood from the very early days of Christianity as one of the highest forms of sacred acts, leading its preparation to be the responsibility of the priests ${ }^{13}$. This custom

${ }^{12}$ I. GONÇALVES, "As festas do "Corpus Christi" do Porto na segunda metade do século XV: a participação do concelho", in Um olhar sobre a cidade medieval, Cascais, 1996, pp. 154-155.

${ }^{13}$ A. AGUIRRE SORONDO, "La elaboración tradicional de las hostias", Kobie (Serie Antropología Cultural), no IV, 1989/90, p. 192 
is reinforced and legislated for from the $13^{\text {th }}$ century, with synodal legislation attributing the exclusive responsibility for the making of the Hosts to be consecrated at the altars to the priests. These figures were identified as Christ Himself, at a time in which the clericalisation of the celebration and the sacredness of the celebrators were accentuated. As Patricia del Pozo Coll confirmed, the moments prior to the Eucharistic celebrations should not be underestimated; the making of the Hosts is equivalent to the moments leading up to the Passion of Christ, evident in the Canon of the Mass ${ }^{14}$. From the $14^{\text {th }}$ century onwards, the production of Hosts with commercial objectives and their making by secular people is documented ${ }^{15}$. However, the Visitations and the synodal legislation insist that they are prepared by clerics and that they should be made in churches, parishes and convents, in designated locations specifically for that purpose ${ }^{16}$.

The Braga Synod celebrated on the $11^{\text {th }}$ of December 1477 by Archbishop D. Luís Pires, legislated on how the priests should make the Hosts and prepare the Wine and Water for the Eucharist ("De como os sacristaaos ham de fazer as ostias e aparelhar o vinho e auga pera missa"). In the churches and monasteries of the Archiepiscopacy of Braga, the responsibility for making the Hosts fell to the priests under the supervision of the beneficiaries. They should be made with wheat flour "on its own", which means pure, without yeast and "que sempre pregunte se he tal e, se tal non for, que a nom recebam"17 and also with very "pure, clear"

${ }^{14}$ P. S. DEL POZO COLL, Op. cit., pp. 30-32 and 35.

${ }^{15}$ B. MONTEVECHI and S. V. ROCCA, Suppellattile ecclesiastica. Dizionari terminologici, Firenze, 1988, p. 148.

${ }^{16}$ We suggest the reading of the recent paper published by M. E. Sánchez Sanz that studies the production of the Eucharistic bread in the Monastery of the Resurrection of Zaragoza, by the nuns of this convent, especially during the 19th century until seventy's 20th century. M. E. SÁNCHEZ SANZ, Op. cit., pp. 5-56.

17 "And should always ask if this is the case, and if not, it should not be accepted". and clean water. The dough should be prepared on a platter or in a new and clean vessel used only for this purpose, in a place which is absolutely clean, without any type of dirt or impurities ${ }^{18}$. The location indicated for the preparation of the hosts is the sacristy of the church. In fact, in the Visitation of 1533 of the parish of São Pedro de Panóias, Álvaro Mendes and Afonso Roiz find "hua chaminé que serve de fazer osteas nella"19, noting the same in the Visitations of the Order of Calatrava, in Spain, which refer to the existence of upper chambers in the sacristies, with chimneys to make the Hosts and ovens to make bread ${ }^{20}$. Many parish churches in England had holes in the walls, sometimes with openings for the smoke to escape, which could have been used for the making of Hosts. Some could be in the presbytery walls, others in the southeast corner of the building, which could be used for other liturgical purposes such as the burning of old canonicals ${ }^{21}$ or images as determined by the Synodal legislation.

The information registered in the Braga Synod repeats the concerns seen in pervious synods, abundantly documented in France, England and Spain. The La Seu d'Urgell Synod, in 1226, determines that the hostiae fiant de farina tridici mundíssima ${ }^{22}$. The Lérida Synod of 1229, confirmed in that of Tarragona in 1239, establishes that the Hosts consecrating the Body of the Lord should be made by the priest, and be made from pure, white flour, without salt or yeast and "with extraordinary care"23. The Codex or Pretiosa of Sant Vicenç de Cardona, written between 1307 and

\footnotetext{
${ }^{18}$ F. CANTELAR RODRÍGUEZ, Op. cit., pp. 95-96.
}

19 "A chimney which serves to make Hosts there". V. P. dos SANTOS, "Visitações de Alvalade, Casevél, Aljustrel e Setúbal", in Documentos para a História da Arte em Portugal, Lisboa, 1969, nº 7, p. 73.

${ }^{20}$ M. R. TORRES JIMÉNEZ, Op. cit., pp. 775 and 1040.

${ }^{21}$ M. RUBIN, Op. cit., p. 43.

${ }^{22}$ L. AMENÓS MARTÍNEZ, "Hostiers i neulers medievals del Museu Episcopal de Vic", Quaderns del Museu Episcopal de Vic, vol. 1, 2005, pp. 93 and 111.

${ }^{23}$ P. S. DEL POZO COLL, Op. cit., p. 32. 
1311, established that one of the priests' competencies was the making of Hosts and in El primer Libre de Fábrica i Sagristia de la Seu de Mallorca, dating from 1327 to 1345, mentions that the Hosts were made in an oven that was in the old sacristy with an auxiliary of iron moulds ${ }^{24}$. The making of the Hosts followed a ritual which was accompanied by the recital of psalms during the entire process, the harvesting, washing and drying of the grains, milling, mixing with water and the respective cooking ${ }^{25}$. Appropriate environments and very clean tables, absolute silence interrupted only by the recital of psalms and care of the cooking flame, which should be moderate and controlled are some of the indications found in the European Synodal Legislation concerning the process of making Hosts, since these were destined to be offered at the altar table ${ }^{26}$.

Bee's wax was the only material considered suitable to be in contact with the Host during the baking process. Associated since the Paleo Christian period with the figure of Christ and the Church itself, bees are privileged witnesses to Transubstantiation, and have been involved in many Eucharistic miracles, recognising the presence of Jesus in the consecrated Host as well as preparing precious tabernacles made of wax to adore, protect and shelter Him from various desecrations ${ }^{27}$. The utensils used to cook the Hosts should be covered in bee's wax and never olive oil or fat which could cause them to $\mathrm{fry}^{28}$. In the aforementioned Braga Legislation of 1477 refers to the fact that the moulds should be sealed shut to better engrave the first Hosts made and that the first Hosts made should be destroyed: "quando as obradeiras canssarem e por ello as ouverem de encerar, que depois da enceradu111.

${ }^{24}$ L. AMENÓS MARTÍNEZ, Op. cit., pp. 93 and

$$
\begin{aligned}
& { }^{25} \text { M. RUBIN, Op. cit., p. } 42 . \\
& { }^{26} \text { Ibídem, p. } 42 . \\
& { }^{27} \text { F. TIXIER, Op. cit., p. } 44 . \\
& { }^{28} \text { M. RUBIN, Op. cit., p. } 42 .
\end{aligned}
$$

ra quebrem as ostias que dali ficarem atee que venham e saiam limpas e puras e de todo fora de cera" ${ }^{\prime 29}$. Aguirre Sorondo, who studied the traditional process of making Hosts, refers to the survival of this practice until the $20^{\text {th }}$ century. During the preparation of the dough the tongs were placed in the flames and, when they were hot, rubbed with a cloth soaked in olive oil or a little bit of beeswax to prevent the dough from sticking to the tongs. For this reason the first Hosts were not approved of, because they were dirty or unusable ${ }^{30}$.To carry out this operation the unleavened dough was spread on the metal plates and the tongs squeezed tightly so that the Hosts would be thin. They would remain there for about ten seconds hardening in the middle of the utensil ${ }^{31}$. To conclude the process the Hosts were separated with scissors or with a "Host cutter", a utensil with a wooden handle, an iron body and circular blade with the same diameter as the Hosts. In the monasteries, the Eucharistic bread should be produced in certain dates like Christmas time, Easter and Pentecost. San Carlo Borromeo prescribed the taking of the host until twenty days after the production of $\mathrm{It}^{32}$.

HOST SHAPE AND SIZE AND PRACTICES TO IMPROVE ITS APPEARANCE

The aforementioned La Seu d'Urgell Synod, in 1226, also indicates that it is obligatory that the Hosts should be cum forma rotunda et circulo integro ${ }^{33}$. This information is corroborated by moulds which have sur-

29 "When the host moulds strain and for him to hear them close, that after the Host mould is opened the Hosts that come from there and leave clean and pure and all out of wax". F. CANTELAR RODRÍGUEZ, Op. cit., p. 96.

\footnotetext{
${ }^{30}$ A. AGUIRRE SORONDO, Op. cit., p. 195.

${ }^{31}$ Ibídem, p. 195.

${ }^{32}$ M. E. SÁNCHEZ SANZ, Op. cit., p. 9.

33 "With round form and entirely circular". L. AMENÓS MARTÍNEZ, Op. cit., p. 111.
} 
vived to the present day. They are all circular and of bigger or smaller sizes depending on the purpose for which the Hosts are destined. The circular form should be understood as a symbol for eternity and perfection ${ }^{34}$, "which have no beginning or end", circular like the earth in accordance with the Universe and like the denarii Judas betrayed Christ for ${ }^{35}$. The moulds resulted in two distinct sizes in many cases: one larger used for the Host to be consecrated at the Altar and other smaller ones for the faithful and sick. The former receive special attention in the Synods and in the Visitations studied, attentive to the fact that they were to be used at the altar and be elevated and then consecrated. In 1533, in the Santa Maria de Alvalade church, visitors encountered moulds which were "of no use", leading to the acquisition of new ones of "marca acustumada e nam tam pequenas como as anteriores" ${ }^{\prime \prime 36}$. In the Visitation to the parish church of São Brás de Figueira, in 1519, the visitors found "bewildering" moulds of four Hosts but which could not be used. The responsibility to acquire new ones or improve the old ones fell to the local council, as referred to in the source material. But the size of the new ones did not please Francisco Coelho and Brother André Dias who thought them too small when they visited the church in 1538: "por quamto as obradeyras em que fazem as hostyas sam muyto pequenas que quamdo se levanta a Deus nam se ve bem a hostya mamdamos aos juízes e ofycyaes que da pubrycaçam desta a tres meses primeyros seguymtes mamdem trocar as dytas obradeyras por outras muito boas e que façam as hostyas gramdes" ${ }^{\prime \prime 3}$.

\footnotetext{
${ }^{34}$ P. S. DEL POZO COLL, Op. cit., p. 50.

${ }^{35}$ Ibídem, p. 43.

36 "A usual type and not as small as the previous ones". V. P. dos SANTOS, Op. cit., p. 73.

37 "For now the host moulds in which are made the Hosts are very small that when it is raised to God it is not seen well the host we order the judges and officers who fabricate these to the three following months to Exchange the said host moulds for other very good ones which make large hosts". J. M. M. L. S. MENDONÇA,
}

The need to increase the size of the Hosts was also the reason for the substitution of existing moulds for new ones in other churches. In 1565, in the Nossa Senhora de Alcaria Ruiva chapel, the visitors ordered "huuns feros d'osteas de boa forma bem lavrados ${ }^{138}$ based on the ones they had of larger sizes, since the existing utensil produced very small Hosts ${ }^{39}$. In the churches of the Order of Calatrava, studied by Torres Jiménez, the visitors also ordered the acquisition of new tools, specifying that those used to "decir misa""40 should be large and visible to the people ${ }^{41}$.

The symbolic importance of the moment of Elevation or "raising to God" led to the making of "large Hosts" which could be easily seen by the faithful, believers in the salutary and prophylactic effects that the Hosts offered. Thus the European practice of placing dark drapes behind the altar is explained. This practice offered a better view of the Host at the moment of Elevation. At the end of the $15^{\text {th }}$ century, Bishop D. Jorge da Costa ordered that black cloth be used on the high-altar of all the churches of the Archiepiscopacy. This arose as a result of complaints from parishioners who could not see the Elevation of the Host: "mandamos a todollos beneficiados do nosso arcebispado que em suas egreias ponham em o altar prinçipal lençooes pretos per tal gisa que quando o ssaçerdote levantar o corpo de deus per bem da color do dicto pano pellos que steverem em as dictas egreias seia bem visto $(\ldots)^{\prime \prime 4}$.

Op. cit., pp. 274 and 295 (Visitation of 1519) and p. 499 and p. 502 for the Visitation of 1538.

38 "Some Host tools of a good form and wellfinished".

${ }^{39}$ M. F. R. BARROS and J. F. BOIÇA-C. GABRIEL, As Comendas de Mértola e Alcaria Ruiva. As Visitações e os Tombos da Ordem de Santiago (1482-1607), Mértola, p. 434.

40 "say Mass".

${ }^{41}$ M. R. TORRES JIMÉNEZ, Op. cit., p. 1040.

42 "We order all the beneficiaries of our archiepiscopacy that in their churches they put on the main altar dark cloths so that when the priest raises the body of 
This practice of erecting dark cloths behind the altar so as to emphasise the whiteness of the Host as it was elevated at the moment of Consecration, accentuated the theatricality and symbolism of the moment. It became common practice all over Europe and documented evidence can be found in Spain, France and England ${ }^{43}$. J. A. Jungagmann documented the practice of running a black cloth between the altar and the altarpiece before the act of Consecration in French and English churches, but consi-dered it a less common practice in Spain. The Portuguese and Spanish Visitations, namely those of the Order of Calatrava studied by Torres Jiménez, countered this idea and demonstrated that it was also a current practice on the Iberian Peninsula between the end of the $15^{\text {th }}$ century and the first half of the $16^{\text {th }}$ century. The guidelines for the use of these cloths demonstrate the approval and incentive, on the part of the Church, of the willingness of the faithful to see the Sacrament. They were not content just with seeing the Sacrament but also in contempla-ting It clearly. The documentation also states that these cloths were normally black or brown, made of linen or velvet, sometimes decorated with red or white crosses (which could be of the Order they represented, if such a situation applied) and their symbolic importance meant that, in some churches, the cloths were removed and stored for safekeeping in the sacristy. These cloths were not very large, they could be either fixed or hung from bars and be raised at the appropriate moment ${ }^{44}$. This carefully thought out scenario refines the association to the Host even further. This process accentuates its translucent, spiritual character through the opulent light illuminating the space, thus favouring the iconographic reading present in the Holy Sacrament. These

god for good to place the said cloths which were in the said churches be well seen (...)". A. C. B. de FIGUEIREDO, "Visitação do Arcebispo de Lisboa (século XV)", Archeologica, 1888, vol. II, pp. 29-30.

${ }^{43}$ S. SEBASTIÁN, Mensaje Simbólico del Arte Medieval. Arquitectura, Liturgia e Iconografía, Madrid, 1994, p. 389; P. S. DEL POZO COLL, Op. cit., p. 44.

${ }^{44}$ M. R. TORRES JIMÉNEZ, Op. cit., p. 1040. practices were aimed at offering Eucharistic piety to the faithful, thus converting the Elevation into an act replete with symbolism.

\section{MATERIALS, OBJECT CLASSIFI- CATION AND PRESENCE IN THE CHURCHES}

Before the $13^{\text {th }}$ century, moulds made from materials such as terracotta, stone and bronze are known of ${ }^{45}$. The oldest of this type of mould dates from the $11^{\text {th }}$ century and is Catalonian in origin ${ }^{46}$. From the $13^{\text {th }}$ century onwards, iron is the material most frequently used in the making of moulds, a fact which can be seen in the Visitations of the Military Orders from the $15^{\text {th }}$ and $16^{\text {th }}$ centuries, with the metal being designated "iron for Hosts". The word obradeira is also used in the sources, above all in texts from the fifteen and sixteen hundreds. Santa Rosa de Viterbo affirmed that this was an old expression, derived from the word oblata, a word of Latin origin referring to the Host before consecration ${ }^{47}$. R. Torres Jiménez confirmed the same in relation to the Visitation of the Order of Calatrava, having identified the double reference to "ostario com que fasen ostias" 48 e "fierros pera fazer ostias" 49 which all the churches had, many times, in duplicate. The same author also suggests that the distinction could be related to the different sizes of the moulds and draws attention to the passage in the Visitation of 1502 to the El Moral church which registered "dos pares de fierros de ostias y outro par de fierros que se disen obleas ${ }^{\prime \prime 50}$.

${ }^{45}$ B. MONTEVECHI and S. V. ROCCA, Op. cit., p. 148.

${ }^{46}$ P. S. DEL POZO COLL, Op. cit., p. 40.

${ }^{47} \mathrm{~J}$. de S. R. VITERBO, Elucidário das palavras, termos e frases que em Portugal antigamente se usaram e que hoje regularmente se ignoram: obra indispensável para entender sem erro os documentos mais raros e preciosos que entre nós se conservam, 1798-1799, ed. de Porto-Lisboa, 1965-1966, vol. II, p. 445.

\footnotetext{
48 "Host mould in which Hosts are made".

49 "Tools to make Hosts".

50 "Two pairs of Host tools and another pair of tools named obleas". R. TORRES JIMÉNEZ, Op. cit., p. 1039.
} 
From the $13^{\text {th }}$ century onwards, a classification is imposed on the tool which remained in place until the $20^{\text {th }}$ century, when these tools were replaced by stamping machines which allowed the mass production of the hosts. The utensil is composed of two parts: a body similar to that of a pair of tongs, with two long handles so as to offer protection from the flames of the oven it was placed in, with a length of, on average, between 70 and $80 \mathrm{cms}$; two metal plates at the extremity used for the pressing of the Hosts which have, on one of the plates, embossed patterns with decorative and symbolic elements ${ }^{51}$. The plates of the Host moulds are normally rectangular in shape, with there being rarer examples of quadrangular, circular, oval, piriform or octagonal shapes. The two parts are joined together by a hook in the shape of an eight. As is usual with tools of this type found in goldsmiths and blacksmiths, they normally have a clasp on one of the arms to link the two arms together after use, thus making it easier to store and prevent damage to the piece.

The Visitations offer very little information on the formal characteristics of these tools. The majority of the registers consulted merely refer to the presence or not of Host moulds in the churches. This information qualified by adjectives such as "boas, muyto boas, meãs, piquenas or grandes" ${ }^{\prime 52}$. What mattered most to the visitors was if the churches did or did not possess this utensil and, if they existed, whether they were in good condition and well polished or not. In the case of the object not being present, one would be ordered. Expression such "quebra-

\footnotetext{
51 Consult http://www.culture.gouv.fr/public/mistral/palissy_fr (accessed 24 October 2015), where it possible to see images of about fifty Host moulds dating from the 13 th to 16 th centuries. The Inventory supplies detailed information on the size, techniques, origin and iconographic elements of the moulds. Also consult the article by L. Amenós in which a study is carried out on the representative collection of medieval Host moulds conserved in the Episcopal Museum of Vic. L. AMENÓS MARTÍNEZ, Op. cit., pp. 100 to 108.

52 "Good, very good, average, small or large".
}

das, velhas, muj velhas, não são pera servir, maltratadas, nam fazem more hóstias, descomcertadas, nom llavrão, velhas que não querem lavrar" 53 , are repeated equally in the sources studied. The content of some of the passages of the Visitation Books demonstrate that the visitors were displeased if the chaplains, priors and commanders had to "go to other parts to collect the Hosts", when they were permanently on duty in the church and could make the Hosts ${ }^{54}$, which proves the generalised practice of Host making in churches.

\section{ICONOGRAPHIC ELEMENTS}

The Visitations of the churches of the Order of Santiago are quite rich in information on the iconography of the moulds, and, consequently of the Hosts made in them. It is possible to verify, however, that the content of the information changes throughout the sixteen hundreds. In the first quarter of the $16^{\text {th }}$ century, sources normally record the existence or not of this type of utensil in the churches, and whether they are large, medium or small, new and good that "seal well", or old that "don't want to seal". The records also reveal the number of Hosts produced at a time by the existing moulds. A statistical analysis of the pieces inventoried in the churches of the Orders of Avis and Santiago allows us to note that two stampings were more frequent, followed by only one stamping ${ }^{55}$. The inventories of liturgical objects in Portuguese dioceses that have survived (and more rarely parish churches), indicate the existence of moulds for four and six hosts. The inventory of Tesouro da Sé de Coimbra, dated 1393, besides referring to a "mould of two Hosts", also refers one

\footnotetext{
53 "Broken, old, very old, not fit to use, badly treated, make no more Hosts, not polished, Old which don't want to be polished".

${ }^{54}$ Information taken from the 1519 Visitation of the São Lourenço church in Galveias. J. M. M. L. S. MENDONÇA, Op. cit., Vol. II, p. 353.

${ }^{55}$ Mentioned in sixteen churches of the Military Order of Santiago.
} 
of iron with four "mould forms", as well as another "forma de seys ostias, que comprarom aos capellães dos egresses" ${ }^{\prime 56}$. The text certainly refers to the Englishmen who came to aid the Master of Avis, the future D. João, the first, during the dynastic crisis of 1383-1385. The Host tool existing in the parish church of S. Brás de Figueira made "four Hosts together" and that of Santa Maria da Graça de Mora, produced "four Hosts each time ${ }^{\prime \prime 57}$. The host moulds inventoried in France, which is a country that has preserved a precious collection of this type of object, many dating from the $13^{\text {th }}, 14^{\text {th }}, 15^{\text {th }}$ and $16^{\text {th }}$ centuries, show a wide variety of shapes and number of impressions, repeating those of four Hosts (two large and two small) as well as two, three, five (one large in the centre and four small), six (two large and four small and an exceptional rectangular piece of eighteen small Hosts (2.7 cm in diameter), distributed in three rows of six, dating from the $14^{\text {th }}$ century and belonging to the parish church of Saint-Gervais et Saint Protais, which has unfortunately disappeared ${ }^{58}$. The Episcopal Museum of Vic also has a precious collection of this type of pieces from the medieval period, of two, three, four, six and seven Hosts ${ }^{59}$, while Aguirre Sorondo states that the most common was of four moulds (two large and two small) ${ }^{60}$, which is consistent with the French inventories consulted.

As the consecrated Host is the Eucharistic symbol par excellence, expressing Christ's ultimate sacrifice with his death on the Cross forgiving the sins of Humanity, the themes

56 "Mould of six Hosts bought to the chaplains of the English". A. J. COSTA, A Biblioteca e o Tesouro da Sé de Coimbra nos séculos XI a XVI, Coimbra, 1983, pp. 35 and 123.

${ }^{57}$ J. M. M. L.S. MENDONÇA, Op. cit., vol. II, pp. 274 and 377.

58 Architecture et Patrimoine, accessed 14 January 2016. URL: http://www.culture.gouv.fr/culture/inventai/patrimoine/, fer à hosties, source Palissy, Réference, PM87000214.

${ }^{59}$ L. AMENÓS MARTÍNEZ, Op. cit., pp. 100-108.

${ }^{60}$ A. AGUIRRE SORONDO, Op. cit., p. 192. shown on the Hosts reflect above all the Passion of the Redeemer. A comparative analysis of the content of the Visitations of the churches of the Military Order of Santiago (which are the richest with respect to this question), the pieces of this nature that still exist $^{61}$ and an analysis of contemporary painting and sculptures corroborate this affirmation. The Visitations studied, from the end of the $15^{\text {th }}$ century and the first quarter of the $16^{\text {th }}$ century, make no reference at all to the decorative elements in the moulds, but those from the second quarter of the sixteen hundreds occasionally refer to the existence of tools with "very good figures" ${ }^{62}$, although without specifying the motifs. From the middle of the $16^{\text {th }}$ century onwards, however, the visitors tend to systematically record the themes represented in these pieces, with those from 1552-1554, ordered by D. João III, being particularly rich in this respect $^{63}$. Despite the fact that an indication of the themes could serve to better identify the objects in future Visitations, we believe that devotional questions, and giving value to the theme of the Passion that this century recognised, could also explain the greater detail of the information.

\section{CRUCIFIXION}

The Crucifixion is the most important image of the Passion, representing Christ's supreme sacrifice, recording the "Precious Blood" spilt by the Saviour, and was the object of greatest devotion from the $13^{\text {th }}$

${ }^{61}$ We used, in this paper, as examples, French and Spanish moulds because in Portugal, there's no reference about this kind of tools from the 15th and 16th centuries. The last Portuguese diocesan inventories have been showing some of this tools dating from the 18th and the 19th centuries. The conclusion of this process of inventorying may reveal more ancient moulds.

${ }^{62}$ As can be read in the Visitation of the church of Santa Maria de Alvalade dated 17th of October, 1533. V. P. dos SANTOS, Op. cit., p. 26.

${ }^{63}$ A. C. C. de SOUSA, Tytolo da prata (...), do arame, estanho e ferro (...), latam cobre e cousas meudas... Objectos litúrgicos em Portugal (1478-1571), Doctoral Thesis defended at the University of Porto, 2010, p. 280. 
century onwards. In the period under study a strict connection between the Cult of the Species and the devotion to the Passion can be seen, with the Mass being understood as a representation of the Sacrifice of Calvary ${ }^{64}$, which explains the iconographic options represented on the Hosts. The theme of Crucifixion is, without a doubt, the most frequent in the documentation studied, with it being referred to on twentytwo of the tools referenced in the churches of Santiago and it could be the crucifixion of "only one impression" or of "two impressions", as well as the themes of Flagellation, Resurrection and Christ in the Sepulchre. In the sources, the frequent use of vocabulary relating to crucifixion, allows one to conjecture if it is a systematic representation of the presence of Christ on the Cross, as opposed to representations that merely include a simple Latin cross, the symbol of Martyrdom, which is a theme equally present on many moulds and visible in many contemporary paintings of the theme ${ }^{65}$. From the $14^{\text {th }}$ century onwards, however, the presence of the dead Christ tends to be seen in the iconography of crosses: the thin, frail, suffering body, accompanied by a pathetic expression which is seen in late medieval art, evoking feelings of pain, anguish and introspection ${ }^{66}$.

The lack of information in the sources means that no more conclusions can be drawn concerning the iconographic characteristics on the theme of crucifixion, making it necessary to examine the Host moulds from the $14^{\text {th }}, 15^{\text {th }}$ and $16^{\text {th }}$ centuries and contemporary artworks to describe it. As it is the most frequent, this representation appears on all the Hosts of a larger size which would have been consecrated and on the smaller ones prepared for the communion of the faithful. The Cross is represented in the centre of the circle, marked by a single,

\footnotetext{
${ }^{64}$ R. TORRES JIMÉNEZ, Op. cit., p. 467.

${ }^{65}$ P. S. DEL POZO COLL, Op. cit, pp. 48-50.

${ }^{66}$ R. TORRES JIMÉNEZ, Op. cit., p. 468.
}

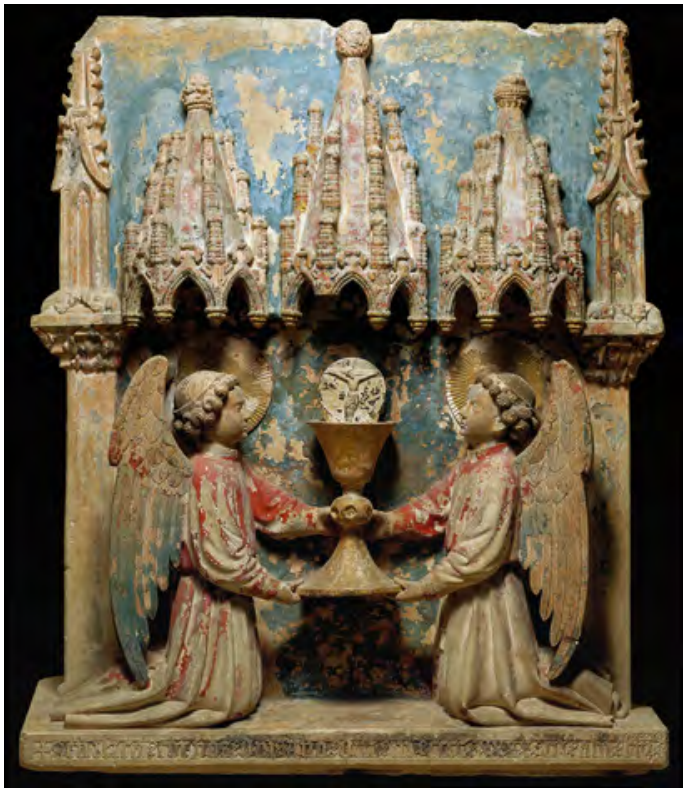

- Fig. 1. João Afonso (attr.). High Altar of the Body of God. 1443. National Museum Machado de Castro, Coimbra. (C) Direção-Geral do Património Cultural / Arquivo de Documentação Fotográfica (DGPC/ADF), Photo from José Pessoa.

continuous line or by two and three concentric lines with an outline which is either broken, smooth, heart-shaped or with stylised vegetable elements. Christ is presented on the cross normally suspended by three nails with a halo (sometimes with a cross), showing a thin body evident in the exposed ribs, with His head tilting to the right (in relief to the left), a somewhat stylised perizoma depending on the chronology (a more naturalist tendency in $15^{\text {th }}$ and $16^{\text {th }}$ centuries and occasionally flowing), legs in the form of a broken line to the right and an overall image of a fragile, suffering body. The stylistic characteristics accompany the illumination drawings of the time, with a direct influence of these in the drawings of the Hosts. The same representational characteristics can be observed in the crucified Christ seen on the Host of the "High Altar of the Body of God", dating from 1443, previously belonging to the former "Capela do Corpo de Deus" in the borough of Santiago, today in the Machado de Castro National Museum, in Coimbra (Fig. 1). 


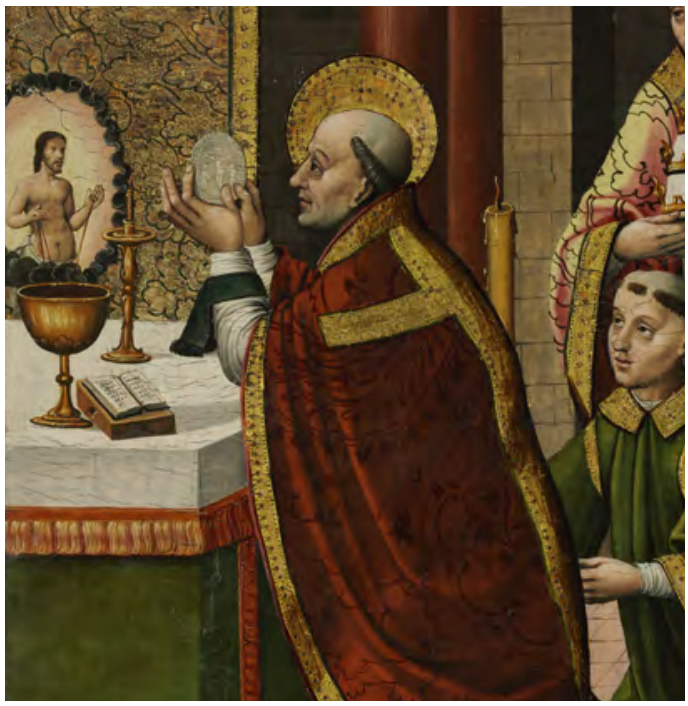

- Fig. 2. Master of Portillo. The Mass of Saint Gregory the Great. Early 16th century. Museum of Fine Arts, Budapest. Photo from Szepmuveszeti Museum, Budapest, Hungary.

\section{Calvary}

In many examples, particularly on the larger Host, the Crucifixion is associated with a representation of a standing Virgin Mary, normally to the left of the cross, accompanied by St. John the Evangelist to the right (a position which is inverted in the Host mould), demonstrating a respect for a balanced and symmetrical composition. The two images are a consistent presence in depictions of crucifixions from the end of the $13^{\text {th }}$ century onwards, representing the Mother and Christ's favourite disciple who, in agony on the cross, told them: "Woman, here is your son" and to the disciple "Here is your mother" ${ }^{\prime \prime 7}$. It is what could be called, in the understanding of Louis Réau, as an analogy to the Ecce Homo, the Ecce Filius and the Ecce Mater ${ }^{68}$. In painted treatments of the time, the profile of the body, gestures and garments of the characters involved also follow the stylistic characteristics of the time when they were conceived: more stylised in the Gothic period and tending to be more naturalistic

\footnotetext{
${ }^{67}$ John 19, 26-27.

${ }^{68}$ L. RÉAU, Iconografía del arte cristiano, Barcelona, 1997, t. 1, vol. 2, p. 518.
}

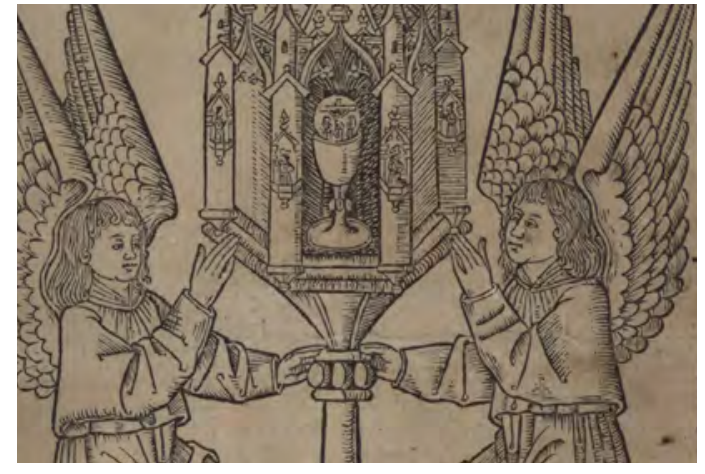

- Fig. 3. Clemente Sánchez de Vercil. Adoration of the Blessed Sacrament. Sacramental. 1502. National Library, Lisbon. URL: http://purl. pt/15164/4/res-149-v_PDF/res-149-v_PDF_24C-R0150/res-149-v_0000_Obra\%20Completa_ t24-C-R0150.pdf

and decorative in the 15 th and $16^{\text {th }}$ centuries. The images are normally presented with halos. The theme is frequently presented on the Hosts used in the Masses of Saint Gregory (Fig. 2). The same question can be studied in the themes referring to the Adoration of the Holy Sacrament, as can be seen in the drawing on the opening page of the Sacramental, wrote by Clemente Sánchez de Vercil and published in 1502, in which the Holy Species are adored by two angels who hold them in an elaborate monstrance (Fig. 3).

\section{Christ at the Column (Flagelation)}

The theme of the Flagellation is the second most frequent theme in the documentation inventoried, referred to in nine works by the expression "Christ at the column" or simply "Column". Matthew, Mark and John refer to Pontius Pilate ordering Him to be "flogged" or "whipped", depending on the translation ${ }^{69}$ and Luke uses the expression "punish"70. None of the Evangelists refer to the execution of the "flagellation" or "punishment" at the column. We are witnessing the most flagrant disproportion, in Réau's understanding, between the evident lack of written description and the prodigious rich-

\footnotetext{
${ }^{69}$ John 19, 1; Mark 15, 15; Matthew 27, 26.

${ }^{70}$ Luke 23,16 and 22
} 


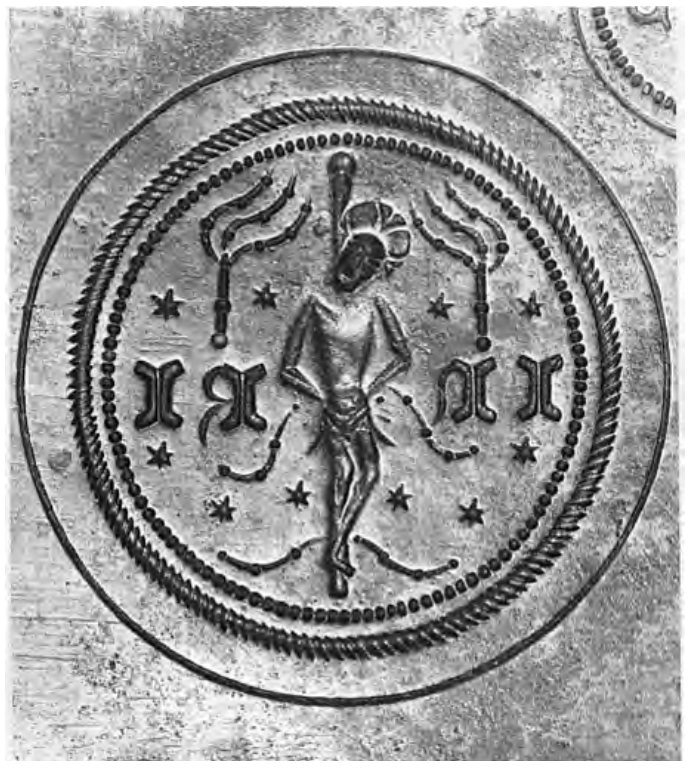

- Fig. 4. Host mould (negative). Saint-Pierre parish church of Peyrelevade. Second half 13th century. (C) Direction du patrimoine, 1998, (C) Inventaire général, ADAGP. Photo from Frédéric Magnoux. URL: http://www.culture.gouv.fr/ culture/inventai/patrimoine/

ness produced by the imagination ${ }^{71}$. At the end of the Middle Ages, the dramatic intensity surrounding the Passion of Christ accentuated the suffering of the Son of God supplicant at the "column". The Revelations of Saint Brigit, which were very popular in the $15^{\text {th }}$ century, contributed to highlighting this drama, elevating, to thousands, the pain of the number of lashes suffered by the Saviour and describing the image of a terrible flogging which ripped the skin and made the blood spurt from a supplicant body. Christ is whipped standing, in accordance with Roman law ${ }^{72}$.

It is necessary to refer to the Host mould images which have survived for us to know the iconographic elements of the theme in the Hosts to be consecrated. The "Host mould" of the parish churches of Saint-Pierre in Peyrelevade, France (Fig. 4), present exactly the same compositional solution: the suffering Christ tied to a column, facing the observer and hands behind His back with the right leg on

\footnotetext{
${ }^{71}$ L. RÉAU, Op.cit., p. 470.

${ }^{72}$ Ibídem, p. 471.
}

the left in a clear allusion to the posture of the body on the cross, from which it is certainly derived, simple perizoma and haloed head. The column is high and thin, in accordance with Art at the end of the Middle Ages. Two whips flank the column, along with Christian symbols. The background is filled with various stars. The composition is inscribed in pearl-shaped or rope-shaped concentric circles and a continuous circle in the outer circle.

\section{SEPULCHRE AND RESURRECTION}

The terms "sepulchre" and "resurrection" are registered separately in the Visitation Books, which suggest a distinct iconography, although the sources clarify nothing as to the compositional and decorative solutions $^{73}$. The term "sepulchre" is referred to in five moulds in churches and hermitages in the land of the Military Order of Santiago $^{74}$ and the "resurrection" just twice ${ }^{75}$, all in Visits taking place in 1554. The artistic inventories and other studies on these pieces make it difficult to distinguish between the two iconographic programmes, since they present different names for the theme.

Taking as a starting point the, certainly conscious, distinction that the visitors made in the $16^{\text {th }}$ century, since they were familiar with the nature of these pieces and aware of the iconographic motifs present in them, and taking into account the various objects inventoried in French and Spanish museums, it is possible to distinguish the themes of "Resurrection", "sepulchre" and Salvator Mundi. An

${ }^{73}$ The sources indicate only the terms "resurrection" and "sepulchre", themes present in Host moulds where there also appear images of "crucifixion" and "column".

${ }^{74}$ São Clemente de Loulé church, Ermida de São Sebastião de Boliqueime church, Nossa Senhora de Martim Longo church, Nossa Senhora da Piedade church in Odeceixe, Santa Maria de Tavira church, all referred to in the Visitation taking place in 1554 . A. C. C. SOUSA, Op. cit., pp. 281-284.

${ }^{75}$ Nossa Senhora da Conceição de Albufeira church and Santa Maria d'Alva de Aljezu church. Ibídem, pp. 281-284. 


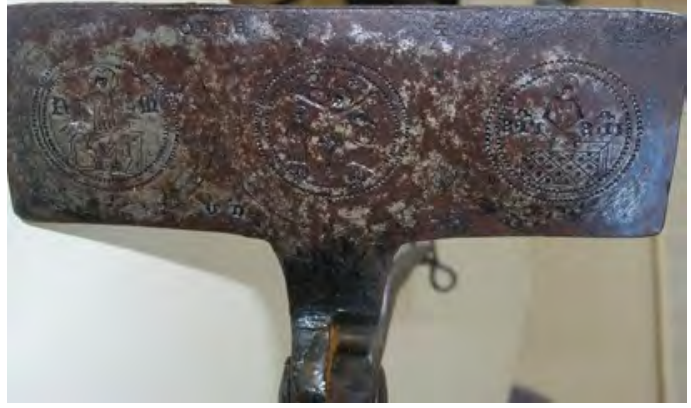

- Fig. 5. Host mould. Saint-Hilaire-Foissac parish church, Limousin, Corréze, France. 15th century. (C) Conservation des Antiquités et Objets d'Art de la Corrèze and (c) Monuments historiques. Photo from Michelle Vallière. URL: http:// www.culture.gouv.fr/culture/inventai/patrimoine/

analysis of Host-making tools belonging to the parish church of Saint-Hilaire-Foissac has helped us, up to a point, to understand this difference: the image on the left mould displays the icono-graphy of Christ in Majesty, the haloed Salvator Mundi in long robes and seated on a throne in the shape of a quadrangular bench with a blessing gesture; the one on the right mould, Christ leaving the tomb, exposing a bare torso, thin and frail, with a haloed head and large hands crossed across the stomach (Fig. 5). It is a theme which perpetuates the iconography of Christus in sepulcro seen in medieval art and which has continued to the present day, an imagine pietatis, a Eucharistic symbol par excellence which was reproduced many times in the $14^{\text {th }}$ and $15^{\text {th }}$ centuries $^{76}$. The Host moulds in the Episcopal Museum of Vic (Fig. 6), dating from the $15^{\text {th }}$ century, also allow us to establish the relationship between the themes of Christ the Man of Sorrows or Merciful Christ with Host iconography ${ }^{77}$. In this, Christ is seen behind the altar, with His hands crossed in front of Him, flanked by the Arma Christi, an image accompanied by the inscription: AVE: VERUM: CORPUS:

${ }^{76}$ L. RÉAU, Op. cit., pp. $46-47$. It should be remembered that the title indicates the importance the theme had in the Mass of St. Gregory.

77 Santa Eulàlia de Riuprimer church, Osona, 15th century, MEV 8117, $70 \mathrm{~cm}$ (dimensions plaques: $14 \mathrm{x}$ 20,5 cm), Museu Episcopal de Vic.

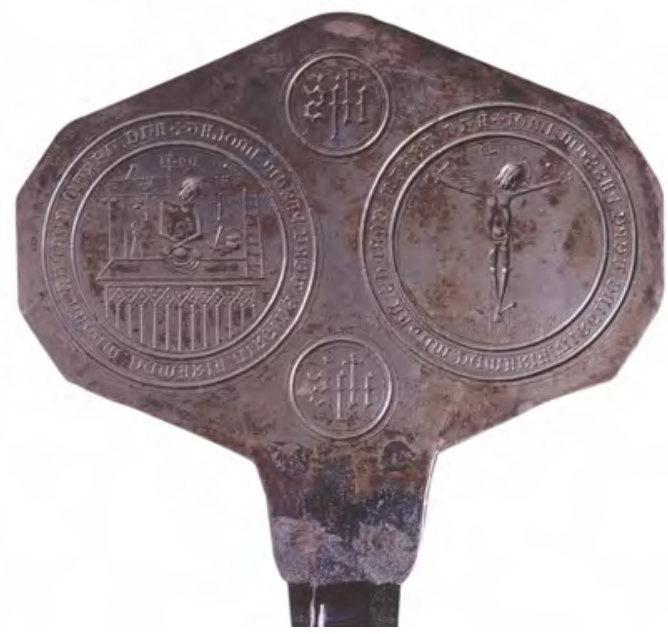

- Fig. 6. Host mould. 15th century. Santa Eulàlia de Riuprimer church, Osona. (C) Museu Episcopal de Vic. Photo from Joan M. Díaz.

NATUM: DE: MARIA: VIRGENE: VERE: PASUM: IMOLA $+^{78}$. From the $15^{\text {th }}$ century onwards, the iconographic themes of the Hosts become more narrative-based and rich in detail, depicting the most popular moments of the Passion and Resurrection. The dogma of the Resurrection, whose final consequences are the Salvation of Man, the conquest of the Eternal Age of the Kingdom of God and the founding of the Church by Christ ${ }^{79}$ are, naturally, present in Host Iconography. Some Host making tools dating from the $16^{\text {th }}, 17^{\text {th }}$ and $18^{\text {th }}$ centuries display the theme in great detail, with "naturalistic" concerns, representing Christ floating above the tomb on a cloud, holding in His right hand a standard cross with a floating Labarum, the symbol of His victory over death ${ }^{80}$ (Fig. 7). In the various examples of the Resurrection of Christ that he analyses, Louis Réau refers, as a mere iconographic curiosity, to the representation of the resuscitated Christ, seated on the tomb with the attitude of a Judge, which can be observed in a German miniature of the $15^{\text {th }}$ century ${ }^{81}$.

${ }^{78}$ L. AMENÓS MARTÍNEZ, Op. cit., p.104.

${ }^{79}$ A. GRABAR, Las vías de la creación en la iconografía cristiana, Madrid, 1993, p. 118.

${ }^{80}$ Which the author does not indicate. L. RÉAU, Op. cit., p. 567.

${ }^{81}$ Ibídem, p. 569. 


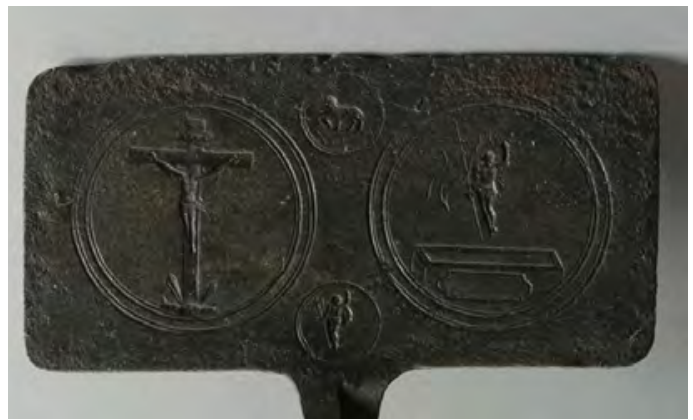

- Fig. 7. Host mould. Saint-Caprais parish church, Sens-Beaujeu, France. 18th century (?) (C) Conseil général du Cher, DADP, Service patrimoine. Photo from François Lauginie. URL: http://www.culture.gouv.fr/culture/inventai/ patrimoine/

The inventoried themes of the host moulds allow us to realise that this representation was, in fact, a recurrent pattern on the Hosts from these centuries. The artistic inventories are normally included in the iconography of Christ in Glory and Christ in Majesty seated on a throne. L. Réau's reinforces the influence of the illuminists on the design and composition of the patterns for the host-making tools. In many of the surviving examples Christ with a halo on His head rises from the tomb with His arms raised and holding a globus cruciger in his left hand and performing a blessing with His right.

\section{Christological symbols}

The Christological symbols normally flank the figure of Christ on the Cross symmetrically, with the most frequent being IHS, XPS (isolated on each side of the cross), INRI or simply I.X, the latter normally present on smaller designs with a letter on each side. Christ's monograms could constitute, however, the main motif engraved in the Host, as Patricia del Pozo Coll has demonstrated, based on Hispanic examples of the iconography from the Masses of St. Gregory. This presence is reinforced by the words of Honorius d' Autun: "The image of the Lord is represented with letters on this bread and thanks to this bread the image of God enters among us" ${ }^{\prime 22}$.

\footnotetext{
${ }^{82}$ P. S. DEL POZO COLL, Op. cit., pp. 54-56.
}

\section{INSCRIPTIONS}

The border of the Hosts could also have inscriptions in Latin, normally written in Gothic script, which were directly related to the Canon, the part of the Mass that occurs between the Elevation and the Agnus Dei. The formula for the consecration of the bread Hoc est enim Corpus Meum ${ }^{83}$, is repeated on a few host moulds ${ }^{84}$, as this oration was the object of great veneration during this period, with miraculous and curative powers being attributed to $\mathrm{it}^{85}$. The expression Agnus Dei. Qui Tollis Pecata M[undi]. M[iserere]. N[obis], allusive to the Sacrifice of Christ, the Saviour and pronounced out loud before the breaking of the bread during the Mass, was considered as a gesture of humility, affirming the preparedness for the Communion ${ }^{86}$. The monogram: IHS Naçarenus Rex Iudeorum ${ }^{87}$, directly related to the crucifixion of Christ is also a recurrent phrase. The phrase Ave Verum Corpus Natum de Maria Virgine Vere Pasum Imolat $^{88}$ is involved in the image of Christ Man of Sorrows on a Host tool conserved in the Vic Museum (Fig. 6). The expression refers to the first three verses of a Eucharistic Hymn dating from the $14^{\text {th }}$ century, which was sung during the Elevation of the Host. This hymn is a poem of meditation on the belief of the real presence of Christ in the Eucharist: Ave verum Corpus natum de Maria Virgine,/ Vere passum, immolatum in cruce pro homine / cujus latus perforatum fluxit aqua et sanguine: / Esto nobis praegustatum mortis in

83 "This is My Body".

${ }^{84}$ L. AMENÓS MARTÍNEZ, Op. cit., p. 101.

85 Torres Jiménez refers to the concerns of Synodal Legislations of the 14th and 15th centuries to enforce the collocation of the mass in parish churches so that the "sacred words of the altar" could be reproduced in a precise way. R. TORRES JIMÉNEZ, Op. cit., p. 1780 .

${ }^{86}$ Ibídem, p. 1236.

87 "Jesus Nazarene King of the Jews". L. AMENÓS MARTÍNEZ, Op. cit., p. 103.

88 "Holy, true Body, truly born of the Virgin Mary, who truly suffered sacrifice". 
examine $^{89}$. The aforementioned formulas are related to the Christological ritual of supplication, repentance and connection to the sacrificed Son, the Lamb of God who takes sins away, who gave life to the World with His death, Jesus who frees the soul of evil which comes from outside and proceeds inwards into Man himself ${ }^{90}$.

\section{CONCLUSION}

The repetition of iconographic motifs present on the Host moulds and the direct relationship of these themes to Eucharistic symbolism lead one to suppose that these followed models established by the Church ${ }^{91}$. The Mass is understood as a renovation of the Sacrifice of the Cross, an allegory of the Passion and presented as a theatrical representation of the death and Resurrection of the Lord ${ }^{92}$. The Fourth Council of Lateran in 1215 reinforced this signification by fixing the real presence of Christ in the Consecrated Species, which led to the affirmation of the Rite of Elevation and its interpretation as the moment of miraculous epiphany of the Son of God. The devotion to the Consecrated Species is followed by the faithful's fervent enthusiasm clearly expressed in the will to "see God" in both the moment of Elevation and the Procession of Corpus Christi which took place from 1264 onwards.

The iconographic elements seen in the stamped Hosts, both for consecration and the communion of the faithful and infirm, (although these were smaller and the motifs adapted to their smaller size), are directly related to the miracle which occurs at the altar and its symbolic significance: Passion, Resurrection and Salvation. The Portuguese Visitations register Crucifixion, Resurrection, Christ at the column and Sepulchre as themes seen in the engravings made on the Host moulds which can be found in museums and religious spaces. They also display the iconography of the Mass which attracted so much attention and devotion during the Low Middle Ages. We can add to these themes the Anagram of Christ, the Latin Cross, the Agnus Dei, the Annunciation and Christ the Man of Sorrows. These could be accompanied by stellar motifs, the Sun and the Moon, Alpha and Omega, the Pelican and Roses sometimes surrounded by Christological inscriptions. The visitors insisted on the acquisition of a new tool designed to make large Hosts as well as the care taken in their use. This reflects the symbolic importance that the Species had for the Church and for the faithful in particular.

89 "Hail true Body born of Mary / Truly having suffered, sacrificed on the Cross for man./ Whose side pierced flowed with water and blood: / Be for us a foretaste of death in the trial." Latin Mass Hymnal. A Concise Guide to the Novus Ord Mass for Catholic Parishes, Washington, p. 102. Accessed 9 July 2016. URL: http://gregorian-chant-hymns.com/publications/booklet-latinmass-hymnal.pdf

${ }^{90}$ R. TORRES JIMÉNEZ, Op. cit., p. 1236.

${ }^{91}$ L. AMENÓS MARTÍNEZ, Op. cit., p. 94; M. E. SÁNCHEZ SANZ, Op. cit., pp. 20-21.

${ }^{92}$ R. TORRES JIMÉNEZ, “Notas para una reflexión sobre el Cristocentrismo y la devoción medieval a la Pasión y para su estudio en el medio rural castellano", Hispania Sacra, LVIII, 118, julio-diciembre 2006, pp. 465466. 